\title{
MATK Gene
}

National Cancer Institute

\section{Source}

National Cancer Institute. MATK Gene. NCI Thesaurus. Code C24587.

This gene is involved in signal transduction within hematopoietic cells. It plays a putative role in the negative regulation of T-cell proliferation. 